\title{
The Practices of the Journalism Bias in the Mainstream Online Media in Covering the 2019 Presidential Election
}

\author{
http://dx.doi.org/10.25008/ikiski.v6i1.475
}

\author{
Nurul Hasfi ${ }^{1}$, Wijayanto ${ }^{2}$ \\ ${ }^{1}$ Department of Communication Science, Universitas Diponegoro \\ ${ }^{2}$ Department of Politics and Governance Science, Universitas Diponegoro \\ Jl. Prof. Sudharto, Semarang 50275 - Indonesia, \\ Coresponding author: nurul.hasfi@live.undip.ac.id
}

Submitted: February 24, 2021, Revised: March 29, 2021, Accepted: May 15, 2021

Accredited by Kemristekdikti No. 28/E/KPT/2019

\begin{abstract}
Objectivity (unbiased) news is an essential journalism principle in covering political news, especially general elections. However, many studies found that violations of this principle become a problem in many elections in different countries. In Indonesia, most researches on this issue have focused more on the traditional media platform. This article aims to explore how online media have covered the 2019 presidential election. This research uses a combination of quantitative and qualitative text analysis methods to investigate 320 online media articles produced by eight leading online media outlets in Indonesia two weeks before the election. By employing the journalism principle of objectivity, the concept of framing and representation, this research found that online media in Indonesia practice biased journalism in reporting the 2019 presidential election. However, each online media outlet has a typical media bias, both quantitatively and qualitatively. This study identified two categories of journalism practice; first, partisan journalism that openly supported particular candidates and at the same time attacked the rival and second, the online media category that tried to be professional, but applied journalism bias by construction framing strategy and representation for the candidate they supported. This research also highlights that the bias of online media journalism was facilitated by the general principle of digital journalism routine in Indonesia that mostly focuses on speed rather than on comprehensive information and also facilitated by the existence of the hyper-link feature that legitimizes the 'cover one side' in a single article.
\end{abstract}

Keywords: Media online; bias; framing; text analysis; 2019 presidential candidate

\section{Introduction}

In a general election, mass media plays a vital role in crossing over the political communication between the elite and the civilians (Lilleker, 2006), among other things, the presidential election. The 2019 presidential election of Indonesia drew the interest of many people as it brought together two strong presidential candidates, Jokowi and Prabowo, who competed in the 2014 presidential election.
The intense competition between the two was closely related to their political communication media, both online and traditional.

Mass media has become an essential means of political communication process to ensure democratic process proficiency. However, many pieces of research have been conducted to prove that during general elections, mass media is not yet fully functional, as stated by Lilleker, and instead, it is used as a 
tool of a political campaign (Sani, 2014; Anuar, 2014) and political propaganda (Tyson \& Purnomo, 2017) to win election contestations. In the context of Indonesia, this misuse of mass media is supported by the issues of the ownership of the mass media in Indonesia that is concentrated (Lim, 2011; Sudibyo \& Patria, 2013a; Nugroho, Putri, \& Laksmi, 2012a), which generate homogenous contents that set back a democratic process. Furthermore, the ownership of the television industry that tends to be Jakarta-centric (Armando, 2014) is regarded as being unable to provide a room for local media owners to develop and generate heterogeneous media. The most updated research related to media ownership in Indonesia in this digital era (Tapsell, 2014) explains that online media has become a part of the media conglomeration which has dominated the online realm.

It is essential to look into the professionalism of online media in Indonesia in covering election news. Currently, the role of online media has become more strategic due to an increase in the number of internet users in Indonesia (Indonesian Internet Service Provider, 2018). This research also expects to bring an open discussion with Tapsell's view (Tapsell, 2017), which states that the media capitalists in Indonesia have become digital conglomerates that eventually take control of the media ecosystem in Indonesia. In other words, the online media industry in Indonesia has become a part of the mass media industry oligarchy and the voice of the elite. In Indonesia's presidential election, the media encounters a dilemma (Jati, 2016) as the media conglomeration issues have caused the television journalism to become polarized, according to Fahadi (2019).

In addition to strengthening the thesis on the degradation of the role of mass media in Indonesia in supporting democracy in elections, this article also complements the discussion on Indonesia's internet and political issues. Internet and politics mainly focused on the roles of nonprofessional media in politics, such as the findings of politics in social media that mainly used to spread hatred (M. Lim, 2017; Hasfi, et al., 2017), political propaganda by the nonmainstream media (Tyson \& Purnomo, 2017) and the sentimental analysis on social media (Haryanto et al., 2019). Online media is a professional media that ideally work with balanced journalism principles (Mcbride, 2014), which are fair, non-partisan, objective, and independent. Although many researchers found the principles as illusions (Seib, 1994), those principles have become normative guidance in political coverage that continues to apply.

In order to elaborate on the findings of this research, this article is divided into two sections; first, the qualitative and quantitative text analysis findings that explored the biased news production practices in the 2019 presidential election and second, the discussion and conclusion that identify the problems in online media in covering the news of the 2019 presidential election.

\section{Theoretical Frameworks}

This research applies two main theories, namely representation and framing, to interpret the result of framing analysis conducted on news texts or articles, which are the objectives of this research. Hall (1997) defined representation as a production process by utilizing language. To represent means to describe, to provide images or imaginations in our mind of an object. In addition, Hall also stated that representing an object also means symbolizing, giving examples, and placing the object in sentences. Meanwhile, to describe the meaning of framing theory, this research refers to Entman's definition (Entman, 2007), in which framing means the attitude of the media in selecting the realistic aspects so that the news is more prominent than other facts.

Based on the concepts of representation and framing, there is a connection between these two concepts in portraying the news objects. For example, Hall (1997) did a representation towards two objects: mental and language that are used simultaneously, so that language used in mass mobilization such as in an election has become crucial in influencing the people's choice on competing candidates. Mental representation explains how the object, people, and event are connected and used in concepts and symbols in the audience or readers' minds. Therefore, the mass media can easily play and connect the symbols which are not directly related to the object, and as a result, it creates a new reality. Meanwhile, the two languages used in interpreting an object are both universal languages that can connect these concepts and ideas.

In this study, the use of framing analysis is to capture how mental and language are played upon in news articles. Pan \& Kosicki's (1993) framing analysis was used by looking into four structures of a syntax (headline, lead, background information, source, statement, and 
conclusion); the script structure by using $5 \mathrm{~W}+$ $1 \mathrm{H}$; the thematic structure that identifies the paragraphs, propositions, sentences or relationships between sentences, and lastly, the rhetorical structure to see how articles emphasize certain meaning or the use of idioms, pictures, and graphics in the news. By using these devices, this research identifies three framings, namely neutral, positive, and negative. At the same time, the representation concept emerges concerning symbols and connotative meanings that come up in those four structures.

\section{Democration, Media Function, and Biased Journalism}

Mass media has become an essential instrument in the process of political communication to ensure the proficiency of the democratic process. This study uses media role indicators in democracy, stated by (Lilleker, 2006), in explaining the role of media in the democratic process. First, as a 'surveillance' or 'monitoring' tool in which the media informs the result of democratic monitoring to the public, whether it is a success or not. Secondly, mass media educates the people about maintaining the objectivity and professionalism of their work. Thirdly, mass media encourages the formation of people's opinions and ensures the interaction between democratic actors, the elite, the public, NGOs, civilians, and other parties. Fourth, the media plays a role as a watchdog that criticizes any government's actions if they are not inclined to the public. Lastly, the media is an instrument of advocacy for the people. Various benchmarks are used to help the researchers identify online media professionalism in Indonesia in covering election news.

In practice, the principles mentioned above have encountered many obstacles in the field as described in this research as issues. This research uses Entman's view (2007) to define biased news. Entman defines objective news as unbiased news that provides a room to every party to make news clarification. Entman defined bias as purportedly distorts or falsifies reality (distortion bias); this term refers to onesided news and does not provide equal treatment for both parties in a political conflict.

\section{Result and Discussion}

The objects of this research are 320 online media news articles that were documented from eight well-known online media outlets in Indonesia: Kompas.co, Tempo.co, Tirto.id,
Detik.com, Sindonews.com, Mediaindonesia.com, Antaranews.com, and Tribunnews.com. This research studied the articles as samples taken for twenty days before the Election Day, namely from 28 March to 16 April 2019. Every day, the researchers selected two top articles from each page of the online media by using keywords, such as 'pemilihan presiden 2019' and 'pilpres 2019' (both mean 2019 presidential election).

To analyze the data, the researchers used quantitative text analysis and framing analysis. The quantitative text analysis depicts media balance based on the total number of news that both support and reject particular presidential candidates. The framing analysis method (Pan $\&$ Kosicki, 1993) was used to see the strategies implemented by each online media outlet in framing the partners of the presidential candidates. The framing analysis has a function to support the finding argumentation of descriptive text analysis which generates representation on both presidential candidates in every news made by the online media.

Several framing devices were used in this research: syntax that focuses on the titles/headlines; script that focuses on news completeness; thematic that focuses on the pronouns; and rhetoric that focuses on the metaphors. To identify biased media, the researchers used biased news principles in political news (Seib, 1994, 22-24), such as covering both sides and the use of pejorative sentences, labeling, opinions, propaganda, and others. From this analysis, various forms of framing emerge, such as the negative, positive, and balance, which supports online media to particular presidential candidates or behavioral balance of an online media in covering the 2019 presidential candidates.

Meanwhile, the quantitative text analysis was conducted on each presidential candidate's representation that was generated from the framing analysis of each online media. This quantitative analysis summed all the representations up, as well as the negative, the positive, and the balance made by each online media. The more balanced media released, the more professional the online media become.

Chart 1 answers the first question: how did online media outlets cover biased news in the 2019 presidential election. However, the quantitative and qualitative text analysis shows that each media outlet has its degree of bias and support techniques. The data shows that Tirto.id is the media outlet with the best professionalism as it proved to have the highest number of 
balanced news reports, while Mediaindonesia.com is considered to be the least balanced media outlet.

In terms of support, there are some conspicuous issues in media coverage. Mediaindonesia.com proved to show the most support for Jokowi in their media coverage, while tirto.id and detik.com were the opposite, with the least support for Jokowi. Kompas, known as the most balanced news organization, was inclined to support Jokowi. The same is true with Tempo.co despite having the well- known reputation of being critical in media coverage.

The researchers categorized Mediaindonesia.com as a partisan media outlet based on the quantitative and qualitative data as it has shown open support for particular presidential candidates. In addition, Mediaindonesia.com has publicly declared support for Jokowi and attacked Prabowo, while other media organizations showed their support or criticism implicitly.

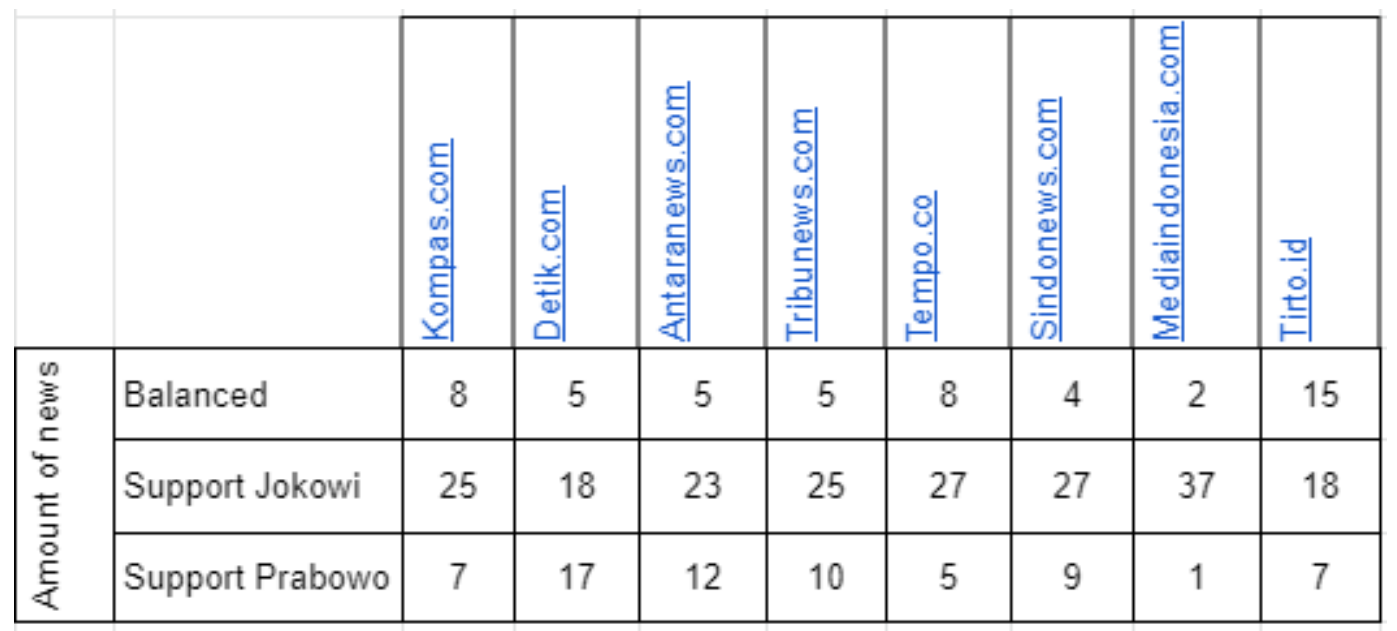

Chart 1. Quantitative Data of Online Media Support on the 2019 Presidential Candidates

Next, the attitude of each online media outlet qualitatively and quantitatively will be elaborated in this journal to show the selected online media biased attitude.

\section{Kompas.com: Support Jokowi-Ma'ruf with Satire}

Quantitative (Chart 1) and qualitative (Table 1) text analysis show even if Kompas.com supported the presidential candidate, Jokowi, quantitatively, it showed professionalism by giving a discussion scope on three framings: news supporting the JokowiMa'ruf pair, news supporting the PrabowoSandi pair, and balanced news. However, the quantitative data shows Kompas.com's framing was dominated by support for the JokowiMa'ruf pair. Nearly 25 or $62 \%$ of news reports showed support for the Jokowi - Ma'ruf pair, seven or $18 \%$ showed support for the PrabowoSandi pair, and eight or $20 \%$ was balanced news.

Chart 1 explicitly describes the bias of Kompas.com in the 2019 presidential election news coverage. This is shown by the low number of balanced news items, which serve as the essential element in measuring media professionalism in election coverage (Seib,
1994). The number of Kompas.com's balanced news reports is much lower than that of its news reports supporting a particular presidential candidate, namely $20 \%$ and $80 \%$, respectively.

Qualitatively (Table 1), the data shows that Kompas.com's support for Jokowi can be presented through the following essential factors. First, Kompas.com showed its support for the Jokowi-Ma'ruf pair by carrying out two framings; first, positive framings about Jokowi which were dominated by news reports on public support for the Jokowi-Ma'ruf pair and second, negative framings about Prabowo in which the media coverage was mainly constructed with Prabowo's claim to win the 2019 presidential election.

Second, the framing of negative news about Prabowo was mainly satire that could be interpreted as support for Prabowo if the reader was not critical of the news due to the space alloted to news about Prabowo. An example of satire is a news report about Prabowo's criticism of the violation of Rohingya Muslims' human rights, whilst in the context of Indonesian politics, there were many news reports on Probowo violating human rights. Prabowo's inconsistency was also shown by a news narrative: Prabowo wins the presidential 
election. The news seemed to positively support Prabowo's victory, but actually it was satirical news as shown by direct quotes of Prabowo's speech which were not sympathetic, for example, 'stolen voice' and his supporters' chant 'Prabowo President.'

Third, there is essential data related to Kompas.com's strategy of framing how it supported Prabowo in the 2019 presidential election. Kompas.com only used Sandiaga's figure without mentioning Prabowo. The framing of positive news about Sandiaga was also a means of Kompas to negatively frame Jokowi, although it only appeared twice: through Sandiaga's narrative criticism of Jokowi's import policies and unsupportive attitude towards the Prabowo-Sandiaga pair by not permitting them to campaign. These framings show that Kompas.com had closed its support for Prabowo and only alloted space for Sandiaga even though it was only in a tiny portion of room.

Table 1. Narratives of Kompas.com for the 2019 Presidential Candidates

\begin{tabular}{ll}
\hline \multicolumn{1}{c}{ Framing } & \multicolumn{1}{c}{ Narratives } \\
\hline Positive Jokowi-Ma'ruf & $\begin{array}{l}\text { Jokowi Won support, Jokowi is Populist, Jokowi Berbhineka, } \\
\text { Jokowi is Competent }\end{array}$ \\
Negative Jokowi-Ma'ruf & Unsupportive, Wrong Import Policies \\
Positive Prabowo-Sandi & $\begin{array}{l}\text { Sandiaga Supported by emak-emak (housewive), Good Political } \\
\text { Strategy of Sandiaga }\end{array}$ \\
Negative Prabowo-Sandi & $\begin{array}{l}\text { Prabowo Claimed a Victory in the Presidential Election, Prabowo } \\
\text { is not Supportive, Prabowo Claimed Unfair General Election, } \\
\text { Prabowo is Emotional, Prabowo is Inconsistent, Prabowo is } \\
\text { Supported by Radical Mulims. }\end{array}$ \\
Balanced & Fair General Election, Debates of Presidential Candidates \\
\hline
\end{tabular}

Lastly, similar to almost most online media outlets, kompas.com tended to produce cover one side news or bias news. Some balanced news items produced by kompas.com usually news articles that cover informative news about the process of the presidential election (see table $1)$.

Detik.com: Polarization support on both presidential candidates within one newsroom

Both qualitative and quantitative text analysis (Chart 1 and Table 1, respectively) shows that Detik.com supported the presidential candidate, Jokowi. The framing of news items showing support for the Jokowi-Ma'ruf pair reached $45 \%$ or 18 news items, and support for the Prabowo-Sandiaga pair reached 17 news items or $43 \%$, and five or $12 \%$ of news items were balanced. Thus, the number of news items showing support for both Jokowi and Prabowo on Detik.com was not much different, meaning that Detik.com quantitatively provided a balanced news coverage for both presidential candidates. However, $88 \%$ of Detik.com's total news reports showed support for each of the presidential candidates, which was well above the total number of its balanced news items. The same is true for other online media outlets.

Meanwhile, negative and positive framings qualitatively emerged from each of the presidential candidates. Unlike Kompas.com and Tirto.com that implicitly showed support, Detik.com consistenly showed explicit support for candidates. Like other typical online media outlets, except Tirto.id, Detik.com applied the principle of cover one side news in the 2019 presidential election news coverage.

Table 2. Narratives of Detik.com for the 2019 presidential candidates

\begin{tabular}{cl}
\hline Framing & Narratives \\
\hline Positive Jokowi-Ma'ruf & $\begin{array}{l}\text { Pro-rakyat, support pluralism, fight hoax news, working, supportive, } \\
\text { Honest, Competent, supported by the public }\end{array}$
\end{tabular}


Negative Jokowi-Ma'ruf

Positive Prabowo-Sandi

Negative Prabowo-Sandi

Balanced

\begin{tabular}{ll}
\hline \multicolumn{1}{c}{ Framing } & \multicolumn{1}{c}{ Narratives } \\
\hline Positive Jokowi-Ma'ruf & $\begin{array}{l}\text { Pro-people, support pluralism, fight hoax news, working, supportive, } \\
\text { Honest, Competent, supported by the public }\end{array}$ \\
Negative Jokowi-Ma'ruf & $\begin{array}{l}\text { Jokowi is not being supportive (complicate campaign clearance), } \\
\text { Jokowi's Policies have failed }\end{array}$ \\
Positive Prabowo-Sandi & $\begin{array}{l}\text { Humble Prabowo, people power, Ahead on the Polls, The Saviour of } \\
\text { the State Money, Sandiaga is close with the Millennials, supported by } \\
\text { the army, Prabowo (is) the President, Supported by Radical Muslims. }\end{array}$ \\
Negative Prabowo-Sandi & $\begin{array}{l}\text { Prabowo is Emotional/Temperamental, Prabowo Supporters are } \\
\text { Provocative, not being supportive, Unusual Campaign, incompetent. }\end{array}$ \\
Balanced & Fair election, Jokowi's Campaign \\
\hline
\end{tabular}

Jokowi is not being supportive (complicate campaign clearance), Jokowi's Policies have failed

Humble Prabowo, people power, Ahead on the Polls, The Saviour of the State Money, Sandiaga is close with the Millennials, supported by the army, Prabowo (is) the President, Supported by Radical Muslims.

Prabowo is Emotional/Temperamental, Prabowo Supporters are Provocative, not being supportive, Unusual Campaign, incompetent.
Detik.com's narratives show three variants of framing: positive and negative framings for both presidential candidates and balanced news (Table 2). Compared to other online media outlets, Detik.com showed a nearly equal number of positive news reports for Jokowi and Prabowo. However, also based on the data, the framings were ambiguous because of the similarity between positive and negative framings for both presidential candidates. This means detik.com was an opportunist when it came to support for both presidential candidates.

Narratives made by Detik.com were polarized into two groups of news by showing the strength and weakness of the opponent as if the newsroom was split into two groups of supporters of the presidential candidates. On the one hand, they showed support for both candidates, while on the other hand they attacked both candidates. Incomprehensive news and fragmented narratives have become the characters of online media outlets that prioritize speed, but this further shows Detik.com for creating fragmented news between Jokowi and Prabowo themes and did not try to create a balanced story in one piece of news.
Antaranews.com: Support Jokowi without Attacking Prabowo

Antaranews.com, has firmly shown its support for the incumbent, Jokowi-Ma'ruf. The quantitative data shows that 23 or $58 \%$ of the news reports supported Jokowi, 12 or $30 \%$ of the news reports supported Prabowo, and five or $12 \%$ of news items were balanced (Chart 1 ). Like other online media outlets, Antaranews.com also had the structure of one candidate's angle in each news item. Other balanced news items were mainly general news related to the implementation of elections, such as the presidential debate and various election preparations.

Meanwhile, the framing analysis shows some specific strategies carried out by Antaranews.com in framing the two presidential candidates (Table 3). First, as a government-funded news agency, Antaranews.com showed support for the incumbent without any negative framings for Jokowi. However, Antaranews.com also did not negatively frame the Prabowo-Sandi pair to a great extent since only one was identified to frame the Prabowo-Sandi pair negatively. 
Table 3. Narratives of Antaranews.com for the 2019 Presidential Candidates

\begin{tabular}{ll}
\hline \multicolumn{1}{c}{ Framing } & \multicolumn{1}{c}{ Narratives } \\
\hline Positive Jokowi-Ma'ruf & $\begin{array}{l}\text { Mega's blessing for Ma'ruf, Jokowi is Optimistic to Win, The Success } \\
\text { of Jokowi's Campaign, Jokowi Supports Sports, Jokowi against Drugs, } \\
\text { Jokowi against Hoax News, Jokowi's Card 'Negara Hadir', } \\
\text { Millennials for Jokowi, Jokowi Wins the Debates, Jokowi's Supporters } \\
\text { in Paris }\end{array}$ \\
Negative Jokowi-Ma'ruf & - \\
Positive Prabowo-Sandi & $\begin{array}{l}\text { Changes made by Prabowo-Sandi, Sandiaga supported by the public, } \\
\text { the Success of Prabowo-Sandi's Grand Campaign, Sandiaga and the } \\
\text { Millennials, Prabowo Won, Prabowo Sandi supported by the public }\end{array}$ \\
Negative Prabowo- Sandi & $\begin{array}{l}\text { Prabowo's Unethical Campaign (children involvement) } \\
\text { Balanced }\end{array}$ \\
& $\begin{array}{l}\text { Jokowi's invitation to succeed in the election, Prabowo's invitation to } \\
\text { succeed in the election, violations, Campaigns on Social Media, The } \\
\text { Control of Campaign Props, Preparation for Elections, Debate for } \\
\text { Presidential candidates, Presidential Elections is not Badar War }\end{array}$ \\
\hline
\end{tabular}

Second, as had happened in other online media outlets, in framing the Jokowi-Ma'ruf pair, Jokowi dominated the news coverage without the appearance of Ma'ruf. Ma'ruf appeared in narratives related to religion, such as the attempt to reject the discourse of the election as Badar War as conveyed by Amin Rais.

Third, in positively framing Prabowo, Antaranews.com also emphasized the figure of Sandiaga Uno instead of Prabowo as had been done by Kompas.com. For example, the Sandiaga framing that he supported the millennials and some of his campaigns in several regions. Meanwhile, positive framing for Prabowo always appeared simultaneously with Sandiaga Uno and never appeared alone.

\section{Tribunnews.com: Satire towards Prabowo to support Jokowi}

The quantitative text analysis indicates that 25 or $63 \%$ of Tribunnews.com's news items showed support for Jokowi, while 10 or $25 \%$ of news items showed support for Prabowo and five or $12 \%$ of news items were balanced (Chart 1). The difference between the number of news items supporting Jokowi and Prabowo significantly reaches 15 compared to that of Detik.com which is recorded at one. The number of news items showing support for Jokowi is the same as that of Kompas.com since both of them belong to the same group, Kompas Group, with $62 \%$ of news items showing support for Jokowi.

Qualitatively, framing analysis shows the framing strategy carried out by Tribunnews.com and Kompas.com is the same and both used satire. In this case, Tribunews.com did not give much negative representation to Jokowi, however, it openly used the negative figure of Prabowo by appliying satirical naration. It seemed that Tribunews.com had given support to Prabowo, but actually it insinuated him in order to support Jokowi (see Table 4). For example, the news about Prabowo admitting that part of one percent of the elite who controlled the wealth in Indonesia during a debate was actually an insinuation to Prabowo's inconsistency in his criticism of the elites taking the money of the state.

Another example of satire towards Prabowo is the news coverge on his discourse of a few things: election fraud, theft of state funds worth Rp1,000 trillion, and his claim of victory by appointing ministries. News in such angle had indeed voiced Prabowo's expression, but it had appeared more negatively in which the identifications was taken from direct quotes of Prabowo's rude words, such as 'stolen', 'rigged', 'lackeys' and many others.

Table 4. Narratives of Tribunnews.com for the 2019 Presidential Candidates 


\begin{tabular}{|c|c|}
\hline Positive Jokowi-Ma'ruf & $\begin{array}{l}\text { Jokowi Builds National Sovereignty, Jokowi is ahead on the polls, } \\
\text { Jokowi and Family went for Umroh, Jokowi Wins the Debate, } \\
\text { Support for Jokowi, Successful Jokowi's Campaign, Sympathetic } \\
\text { Jokowi Supporters, Ma'ruf's Visions, Ma'ruf Is Optimistic to Win }\end{array}$ \\
\hline Negative Jokowi-Ma'ruf & Jokowi and Money Politics Case \\
\hline Positive Prabowo-Sandi & $\begin{array}{l}\text { Prabowo has the People's Power, No.8 as Victory Symbol for } \\
\text { Prabowo, Prabowo is Optimistic about Winning (the election), } \\
\text { Sandiaga does not receive salaries, Prabowo supported by Solo, } \\
\text { Sandiaga is Supportive }\end{array}$ \\
\hline Negative Prabowo-Sandi & $\begin{array}{l}\text { Prabowo weakens the KPU's function, The Cooling-Off Periods for } \\
\text { Prabowo's Campaign, Prabowo is a Conglomerate, Prabowo's } \\
\text { Campaign is Unusual, Prabowo's Appeal to Choose according to } \\
\text { Conscience, Prabowo Wants to Save the State Money }\end{array}$ \\
\hline Balanced & $\begin{array}{l}\text { The Ma'ruf Meme case is solved, Presidential Candidates Clothing: } \\
\text { Symbol of Nationalism, Second Campaign of both Candidates }\end{array}$ \\
\hline
\end{tabular}

\section{Tempo.co: Refuses Prabowo by Omitting Positive Narratives \\ Tempo.co had the same framing technique as Kompas.com and Tribunnews.com which supported Jokowi by giving satires to Prabowo. The quantitative data (Chart 1) shows that $67 \%$ of its news reports support Jokowi, only 13\% show support for Prabowo, and $20 \%$ are balanced.}

Table 5 shows unique framing in which no negative framing was given to the JokowiMa'ruf pair as carried out by Antaranews.com. The negative framings of Prabowo had different variants compared to other framings. Tempo tended very much to reject Prabowo as shown by its negative framings in which it directly appointed Prabowo's figure. While the positive framings of Prabowo mainly focused on his running mate, Sandiaga, as carried out by Kompas.com.

Table 5. Narratives of Tempo.co for the 2019 Presidential Candidates

\begin{tabular}{ll}
\hline \multicolumn{1}{c}{ Framing } & \multicolumn{1}{c}{ Narratives } \\
\hline Positive Jokowi-Ma'ruf & $\begin{array}{l}\text { Jokowi is anti-authoritarian, Jokowi is Islamic, Jokowi is close to the } \\
\text { People, Jokowi's Red and White Concert is a Success, Jokowi is } \\
\text { ahead on the polls, Jokowi is free from KKN (corruption, collusion } \\
\text { and nepotism) }\end{array}$ \\
Negative Jokowi-Ma'ruf & - \\
Positive Prabowo-Sandi & $\begin{array}{l}\text { Prabowo is supported by Dahlan, Prabowo-Sandi does not receive } \\
\text { salaries, Sandiaga will buy Indosat, Sandiaga is supported by the } \\
\text { people of Papua, Sandiaga is Supportive }\end{array}$
\end{tabular}


Negative Prabowo-Sandi

Balanced
Public Fund Assistance is only for Good Image, Prabowo is a Mining Entrepreneur (an elite), Prabowo Claims that the Election is Fraud, Prabowo's Claim as a Truth Teller, Prabowo's Claim as a Changer, Prabowo claims Victory, Prabowo is temperamental and rude, Prabowo does not have ethics (a bastard elite), Prabowo is not generous, Prabowo breaks the cooling-off periods, the High Cost of Prabowo campaign

Competition before the presidential election, Fake Ballots, Election Violations, Prabowo Campaigns in the Cooling-off Periods, Jokowi monitors quick counts, the second Presidential Candidate Campaign
The framing techniques used by tempo.co also had a similarity to Kompas.com and Tribunnews.com, in which it used satire strategy to frame Prabowo negatively. Tempo.co used cynical facts as satire towards Prabowo but it was shown positively. For example, the news report about a mosque inaugurated by Prabowo during the cooling-off period. It was an excellent example of noble acts, but on the other hand, it showed that Prabowo had violated the campaign regulations. Another example is the news reports of Prabowo's 'President' title, even though it was still in the campaign period.

Sindonews.com: Support for Jokowi and Propaganda Texts for Prabowo

The descriptive-quantitative data analysis shows that Sindownews.com supported Jokowi by writing the same number of news reports as that of Kompas.com, Tribunnews.com, and
Antaranews.com. Of the selected samples, 27 news reports showed support for Jokowi, nine news reports showed support for Prabowo, and four news reports were balanced. The quantitative data also shows ten news items were balanced and $90 \%$ of news items were biased.

The framing analysis shows that Sindonews.com had similarities with Tempo.co and Antaranews.com, in which it did not create negative framing for the Jokowi-Ma'aruf pair. Meanwhile, it used only the figure of Sandiaga to create positive frames of the Prabowo-Sandi pair. In addition, the positive framing of Prabowo was much developed by using the figure of his supporters. For example, it framed Prabowo-Sandi's supporters who sympathetically followed the campaign.

Table 6. Narratives of Sindonews.com for the 2019 Presidential Candidates

\begin{tabular}{|c|c|}
\hline Framing & Narratives \\
\hline Positive Jokowi-Ma'ruf & $\begin{array}{l}\text { Jokowi is supported by Muslims, Jokowi's Campaign was Successful, } \\
\text { Ma'ruf was supported by the Public, Jokowi was a Hard Worker, } \\
\text { Ma'ruf was close to millennials, Kartu Sakti Jokowi, Jokowi supports } \\
\text { Sports, Jokowi won the debate, Jokowi supports the Creative Industry, } \\
\text { Jokowi is ahead on the polls, Jokowi's Kartu Sakti Program, Jokowi is } \\
\text { supported by Farmers }\end{array}$ \\
\hline Negative Jokowi-Ma'ruf & - \\
\hline Positive Prabowo-Sandi & $\begin{array}{l}\text { Sandi is Democratic (Confirmation of the People's Power), Sandiaga } \\
\text { is close to Millennials, Prabowo's Supporters are Sympathetic, } \\
\text { Prabowo is close to Sri Sultan HB, Sandiaga-Prabowo and the People's } \\
\text { Power, Prabowo is Islamic, Sandi's Programs }\end{array}$ \\
\hline
\end{tabular}


Negative Prabowo-Sandi

Balanced
Prabowo's Promises, Prabowo is associated with Bung Karno (Slammed the Podium), Accusation of Fraud Election, Prabowo and Bung Tomo, Prabowo 'Won', Prabowo is Emotional, Prabowo's High Tone Voice, Prabowo Speaks without Data/Evidence

Fair general election, the Positive Things of both Presidential Candidates, the Activities of both candidates
There were no significant differences between Sindonews' and other online media outlets in terms of positive framings for the Jokowi-Ma'ruf pair in which it used the figures of the pair. It also used similar narratives, such as support, successful campaigns, successful debates, and support from millennials, farmers, creative industries, and many others.

Meanwhile, the negative framing of the Prabowo-Sandi pair showed an unique framing method used by Sindonews.com to direct the creation of an angle that was seemingly to be propaganda. For example, a propaganda transfer that likened Prabowo to Soekarno and Bung Tomo. In addition to that, most of its framings also used satire method, especially for Prabowo as carried out by Kompas.com, Tempo.co, and Tribunnews.com.

Tirto.id: A balanced online media, although there were some attempts to support Jokowi

This research finds that Tirto.id is the most professional media outlet due to its highest number of balanced news reports compared to that of other online media outlets, which reached 15 or $37 \%$ of news reports. There were 18 news reports showing support for Jokowi or $45 \%$ of the total samples, and seven news reports or $18 \%$ showing support for Prabowo (Chart 1). The data shows that even though Tirto.id had a high rate of balanced news, the number of its biased news items was higher than that of its balanced news at 26 or $63 \%$.

The fundamental difference between Tirto.id and other online media outlets is that its news reports were in-depth, comprehensive, and analytical. These characteristics can be seen from its balanced news in which it created time interval between news reports of both presidential candidates by carrying out interviews with unbiased experts and interviewees. Meanwhile, qualitatively, the data shows that Tirto.id had various angles in covering the 2019 presidential election compared to other online media outlets, as shown in Table 7. Tirto.id covered critical, balanced news reports that evaluated both candidates, while other online media outlets' balanced news report was merely about preparations and implementation of the presidential election. Tirto.id covered many issues, such as work program, campaign methods, political imaging (pencitraan), analysis of the presidential candidates' debates, criticism of the presidential candidates' communication styles, and many others.

Table 7. Narratives of Tirto.id for the 2019 Presidential Candidates

\begin{tabular}{cl}
\hline Framing & \multicolumn{1}{c}{ Narratives } \\
\hline Positive Jokowi-Ma'ruf & Jokowi's Promises, Jokowi is ahead on the polls, Jokowi's \\
& Campaign, Jokowi is a Hard Worker, Jokowi Outplayed the \\
& Debate, Jokowi is Optimistic, Jokowi 'grabs' the Millennials, \\
& Jokowi is free from KKN (corruption, collusion and nepotism), \\
& Jokowi Goes International
\end{tabular}

Negative Jokowi-Ma'ruf

Positive Prabowo-Sandi

Negative Prabowo-Sandi
Prabowo is Rigged, Prabowo is Islamic, Prabowo is Optimistic, Sandiaga's Programs

Prabowo is Rude, Prabowo Lost the Debate, Prabowo Legalised His Victory 
Balanced

Prabowo's Ministries, Salary Increase for the Civil Servants, Jokowi Campaign is Stagnant, Narrative of Kartu Prakerja (preemployment cards), Jokowi Clarifies Hoax News, Debates on Surveys, Narrative on Prabowo's Characters, Political Imaging (pencitraan) of the both presidential candidates, Hoax News of both presidential candidates, Campaign Methods, Fair Election, Program from both Presidential Candidates, the Army (TNI) and Vice-President Candidates

Tirto.id showed support for the JokowiMa'aruf pair by creating positive framing without negative framing of Jokowi. Positive framing appeared with narrative similar to that of other online media outlets, such as in the campaign, Jokowi was ahead on the polls, and Jokowi's internationalized profile (Table 7).

Regarding news reports supporting Prabowo, Tirto.id had similarities with Kompas.com, Tribunnews.com, and Tempo.co, which used satire. For example, it framed Prabowo as being emotional, Prabowo claimed victory before the Election Day, and Prabowo lost in a debate.

Unlike Antaranews.com, Kompas.com, and Tempo.co, which excluded Prabowo from any positive narratives, Tirto.co still gave positive news framing to Prabowo by using such narratives as: Prabowo is Islamic and Prabowo is Optimistic.

\section{Mediaindonesia.com: A partisan Media that supports Jokowi}

Mediaindonesia.com is an online media outlet that showed biased news coverage, so that the researchers categorized it as partisan media. Mediaindonesia.com only had two balanced news or $5 \%$. The rest showed support for both candidates with nearly $92 \%$ or 37 of news supporting Jokowi and only one news supporting Prabowo. Mediaindonesia.com had firmly and explicitly shown its support for Jokowi and had also openly attacked PrabowoSandiaga (Table 8).

Table 8. Narratives of Mediaindonesia.com for the 2019 Presidential Candidates

\begin{tabular}{ll}
\hline \multicolumn{1}{c}{ Framing } & \multicolumn{1}{c}{ Narratives } \\
\hline Positive Jokowi-Ma'ruf & $\begin{array}{l}\text { Jokowi is close with the army (TNI), Jokowi is ahead on the polls, } \\
\text { Jokowi's supporters are dominating (dominant narrative), Jokowi's } \\
\text { Campaign is packed, Jokowi is supported by Muslims, Jokowi is } \\
\text { humane, Jokowi won the debate, Jokowi's infrastructure, Ma'ruf is } \\
\text { supported by homemakers, Jokowi is supported by Millennials, } \\
\text { Jokowi is in control of the Military }\end{array}$ \\
Negative Jokowi-Ma'ruf & - \\
Positive Prabowo-Sandi & Prabowo's supporters in Sumatera \\
Negative Prabowo-Sandi & $\begin{array}{l}\text { Prabowo is rude (to homemakers), Prabowo is guilty (Ratna S. Case), } \\
\text { Sandiaga is rigged }\end{array}$ \\
Balanced & Activities on the day of voting \\
\hline
\end{tabular}


The framing analysis shows some essential things which generally support the findings of the quantitative data above. First, the narratives supporting Jokowi had the most variations (Table 8). Some narratives that had emerged were intentionally made to counter the positive narratives of Prabowo, such as support from emak-emak (an Indonesian term used to refer to housewives). In this regard, Mediaindonesia.com came up with a different narrative to describe that Prabowo was rude to emak-emak. Second, Mediaindonesia.com's support for Jokowi was also shown by the absence of negative narratives against Jokowi as found in other online media outlets: Antaranews.co.id, Tempo.co, Tirto.id, and Antaranews.com.

Mediaindonesia.com negatively narrated Prabowo by explicitly attacking him. There were at least two methods used: news angle about Prabowo being emotional and having 'rude' character, and then comparing the characters with Jokowi's positive characters simultaneously in one piece of news. In addition, Sandiaga Uno, who had always been used as a means of support for Prabowo in other online media, also received a negative narrative on Mediainodnesia.com.

\section{Bias journalism in Covering the Presidential Election \\ Using the text analysis, the researchers} have identified that only Tirto.id applied slow journalism out of eight online media outlets, chosen as samples. The remaining online media outlets used a speedy approach with cover one side principle. Furthermore, although the online media claimed to provide para-links as a news confirmation mechanism, this practice reduced the quality of the news coverage. As evidence, Tirto.id, which applied slow journalism news pattern, produced more in-depth news articles and guaranteed the more objective news article.

Hardnews reporting mechanism with a single angle or cober one side might still be accepted if the news contains neutral information. However, this kind of practice can be problematic issue whenever it is applied in covering the election. This research identifed the bias news reports in four framings: positive and negative framings for Jokowi-Ma'ruf, positive and negative framings for Prabowo.

First, there are two methods of framing positively Jokowi-Ma'ruf, including by using explicit wordings to show Jokowi's positive sides and second, by using cynical satire towards Prabowo. Detik.com and Antaranews.com implemented explicit support by using straightforward words. While Kompas.com, Tempo.co, Tribunnews.com, and Tirto.id applied satire framing strategy towards Prabowo-Sandiaga to show their support for Jokowi-Ma'aruf. The use of satire technique was to desert the obligation by giving a room to Prabowo in the newsroom. These media outlets had tried to be professional, but they were still biased.

Second, the data shows that the media did not use negative framing of Jokowi-Ma'ruf. This shows that online media in Indonesia tend to give support to this particular presidential candidate. This finding supports the previous research that addressed Jokowi as a media darling in the context of the 2014 presidential election and the 2019 presidential election.

Third, quantitatively, there were only a few positive framings for Prabowo in all online media outlets. Some of them seemed to support Prabowo, but instead they used Sandiaga Uno, the vice president candidate, to positively frame this pair, as done by Kompas.com, Antaranews.com, and Tempo.co. It can be said that these three media editorials rejected the figure of Prabowo by not providing positive news coverage about him. However, Detik.com still explicitly made positive representations for Prabowo.

Fourth, the online media negatively framed Prabowo-Sandi by using two techniques, explicitly and implicitly. Detik.com, Antaranews.com, Sindonews.com, and Mediaindonesia.com carried out negative framing towards this pair explicitly. While Kompas.com, Tempo.co, Tribunnews.com, and Tirto.id used the implicit technique to frame this pair. The implicit techniques include putting forward Prabowo's attitude and statements that were disliked by the Indonesia people, such as representation of Prabowos's rude attitutes.

Finally, balanced news which is defined as cover both/many sides was only found on Tirto.id, meanwhile other online media outlets tended to carry out similar patern, cover one side in their sigle stories.

\section{Conclusion}

This study concludes that online media in Indonesia have a strong tendency to practice biased journalism in covering the presidential election. Based on the findings, only one online media outlet, tirto.id has consistently practiced cover both/many side news principle. However, 
this study also shows that each online media outlet had different level of biased news based on its ideology. This is supported by the findings that the highest level of biased journalism was done by mediaindonesia.com, an online media outlet owned by politician Surya Paloh, a staunch supporter of Jokowi.

Finally, this research found two online media models in covering general election, first, partisan online media and second, media that tried to be professional but implictly wrote biased news by applying framing strategy. The first model shows their open support for a particular candidate, while at the same time attacking the other candidate. The second model is practiced by most of online media outlets by supporting a particular candidate and providing strategic support implicitly. In this case, the online media tried to be professional. However, they had political and economic interests in the victory of a particular presidential candidate.

\section{Acknowledgements}

This research was funded by the Research Development and Application (Riset Pengembangan dan Penerapan) of Diponegoro University.

\section{References}

Anuar, M. K. (2014). Election Advertising in the Mainstream Print Media: Politics for Sale during Malaysia's 2013 General Election. Asia Pacific Media Educator, 24(1), 77-94. https://doi.org/10.1177/1326365X145392 05

Armando, A. (2014). The greedy giants: Centralized television in postauthoritarian Indonesia. International Communication Gazette. https://doi.org/10.1177/174804851452410 6

Asosiasi Penyelenggara Jasa Internet Indonesia. (2018). Infografis Penetrasi \& Perilaku Pengguna Internet Indonesia. Teknopreuner.

Entman, R. M. (2007). Framing bias: Media in the distribution of power. Journal of Communication, 57(1), 163-173. https://doi.org/10.1111/j.14602466.2006.00336.x

Fahadi, P. R. (2019). Oligarchic Media Ownership and Polarized Television Coverage in Indonesia's 2014 Presidential Election. Jurnal Komunikasi Ikatan
Sarjana Komunikasi Indonesia, 4(2), 7786.

https://doi.org/10.25008/jkiski.v4i2.328

Hall, S. (1997). Representation: Cultural Representations and Signifying Practices. The Open University (Vol. 1). London: The Open University.

Haryanto, B., Ruldeviyani, Y., Rohman, F., Julius Dimas, T. N., Magdalena, R., \& Muhamad Yasil, F. (2019). Facebook analysis of community sentiment on 2019 Indonesian presidential candidates from Facebook opinion data. Procedia Computer Science, 161, 715-722. https://doi.org/10.1016/j.procs.2019.11.17 5

Hasfi, N., Usman, S., \& Santosa, H. P. (2017). Representasi Kepemimpinan Calon Presiden Di Twitter. Jurnal ASPIKOM, 3(2), 270-284.

Jati, W. R. (2016). Media and Political Persuasion: The Role of Media in Indonesia Presidential Campaigntle. Jurnal Politik LIPI.

Lilleker, D. G. (2006). Key concepts in political communication. Key Concepts in Political Communication. https://doi.org/10.4135/9781446212943

Lim, B. M. (2011). 9 . Democratised / Corporatised: Contesting Media in the Post-, (May 1998).

Lim, M. (2017). Freedom to hate: social media, algorithmic enclaves, and the rise of tribal nationalism in Indonesia. Critical Asian Studies, 49(3), 411-427. https://doi.org/10.1080/14672715.2017.13 41188

Mcbride, K. T. R. (2014). The New Ethic of Journalism: Principles for the 21st Century. SAGE Publications, London.

Nugroho, Y., Putri, D. A., \& Laksmi, S. (2012). Mapping the Landscape of the Media Industry in Contemporary Indonesia. Report series: Engaging Media, Empowering Society: Assessing media policy and governance in Indonesia through the lens of citizens' rights.

Pan, Z., \& Kosicki, G. M. (1993). Framing analysis: An approach to news discourse. Political Communication. https://doi.org/10.1080/10584609.1993.99 62963

Sani, M. A. M. (2014). Malaysia's 13th General Election: Political Partisanship in the Mainstream Print Media. Asia Pacific Media Educator, 24(1), 61-75. https://doi.org/10.1177/1326365X145391 
86

Seib, P. (1994). Campaign and Conscience:the ethics of political journalism. Greenwood publishing groub.

Sudibyo, A., \& Patria, N. (2013). The Television Industry in Post-authoritarian Indonesia. Journal of Contemporary Asia. https://doi.org/10.1080/00472336.2012.75 7434

Tapsell, R. (2014). Platform convergence in Indonesia: Challenges and opportunities for media freedom. Convergence. https://doi.org/10.1177/135485651453152
7

Tapsell, R. (2017). Media Power in Indonesia: Oligarchs, Citizens and the Digital Revolution. New York: Rowman \& Littlefield International Ltd.

Tyson, A., \& Purnomo, B. (2017). President Jokowi and the 2014 Obor Rakyat controversy in Indonesia. Critical Asian Studies, 49(1), 117-136.

https://doi.org/10.1080/14672715.2016.12 58585

identified to frame the Prabowo-Sandi pair negatively. 